\title{
SERUM C-REACTIVE PROTEIN AND INTERLEUKIN6 LEVELS IN NEONATAL SEPSIS
}

\author{
Dilara Içă̆asioğlu ${ }^{1}$, Hüseyn Çaksen ${ }^{2}$, Idris Sütçu ${ }^{1}$, Ömer Cevit ${ }^{1}$ \\ Cumhuriyet University, Faculty of Medicine, Sivas, Turkey: Department of Pediatrics ${ }^{1}$; Yüzüncü Yil University, Faculty of \\ Medicine, Van, Turkey: Department of pediatrics ${ }^{2}$
}

Summary: In this article, we studied complete blood count, serum C-reactive protein (CRP) and interleukin (IL-6) levels in 30 newborn infants with sepsis at admission, in the $24^{\text {th }}$ hour of admission and at the end of the treatment. Our purpose was to determine the relationship among these parameters in the early diagnosis of neonatal sepsis. In our study, there was not a significant difference in white blood cell (WBC) and thrombocyte count among the values of the first, $24^{\text {th }}$ hour and end of therapy in the study group $(P>0.05)$. However, there was not a significant difference in $\mathrm{B} / \mathrm{N}$ ratio among the values at admission, $24^{\text {th }}$ hour and end of therapy in the study group $(P>0.05)$. Both serum CRP and IL-6 levels were found to be significantly higher than those of control subjects at the beginning $(P<0.05)$. Similarly, the values obtained on the $24^{\text {th }}$ hour were also elevated. However, at the end of therapy both decreased to normal level $(P<0.05)$. Based on these data, we think that serum CRP levels only which is a simple method may be used in the diagnosis of neonatal sepsis. However, WBC and serum IL-6 levels may be useful to establish mortality, because there was a statistically significant difference for these parameters between the survivors and deaths $(P<0.05)$.

Key words: C-reactive protein; Interleukin; Newborn; Sepsis

\section{Introduction}

The early diagnosis of sepsis in newborn infants is an important problem because the early signs and symptoms of septicemia in term or preterm infants are usually nonspecific $(2,3)$. Serum C-reactive protein (CRP), IL0-6, IL-1ra (interleukin-1 receptor antagonist), tumor necrosis factor (TNF)-alpha, soluble TNF receptors (p55 and p75) and circulating intercellular adhesion molecule-1 (cICAM-1) concentration have been used in order to determine early diagnosis of sepsis $(1,4,5,6,7,8,9,10,11,12,14,15)$. In this article, we studied complete blood count, serum CRP and IL-6 levels in newborn infants with sepsis to determinate the relationship among these parameters in the early diagnosis of neonatal sepsis.

\section{Material and Methods}

The study includes 30 infants with neonatal sepsis and 10 healthy age-matched control infants. In the diagnosis of sepsis, inclusion criteria included physical signs of infection and respiratory or cardiovascular dysfunction. Physical symptoms of infection were defined by the presence of at least two of the following: feeding intolerance, abdominal distension, lethargy, irritability, temperature instability, hyperbilirubinemia and hepatosplenomegaly (8).
In all patients complete blood count, serum CRP and IL-6 levels were determined at admission, in the $24^{\text {th }}$ hour of admission and at the end of the treatment. In healthy infants these parameters were studied only at admission. Complete blood count was counted by electronic empedens method in the automatic counter (Medonic CA 610, Sweden). Serum CRP and IL-6 concentrations were measured by latex agglutination and enzyme linked immunosorbent assay methods, respectively. The normal ranges of hemoglobin, white blood count (WBC) and thrombocyte count were $14-18 \mathrm{~g} / \mathrm{dl}, 5000-20,000 / \mathrm{mm}^{3}$ and $150,000-450,000 /$ $\mathrm{mm}^{3}$ respectively (13). The values of $>0.2,>6 \mathrm{mg} / \mathrm{dl}$ and $>8 \mathrm{pg} / \mathrm{ml}$ were accepted as positive for the band/neutrophil (B/N) ration, serum CRP and IL-6 levels, respectively.

A combination of cefotaxim plus ampicillin-sulbactam was initiated in all patients, but antibiotics were changed in required infants according to the antibiogram. Statistical analyses were performed by using Mann-Whitney U test, Kruskal-Wallis vaiance analysis and Chi Square test.

\section{Results}

Of 30 infants with sepsis, 21 were boys and nine were girls, and of the healthy infants six were boys and four were girls. There was no significant difference in age at admission, gestational age, weight and sex between the groups 
$(P>0.05)$ (Tab. 1). Blood culture was positive in $14(47 \%)$ infants. The microorganisms isolated from blood cultures were as follows; coagulase negative Staphylococcus in four (28.5\%) infants, Enterobacter in four (28.5\%) infants, Escherichia coli in three (21.5\%) infants, Klebsiella in two $(14.5 \%)$ infants and Serratia in one (7\%) infant. Four (13.3\%) infants died in the study group.

Table 1 presents clinical and laboratory findings of the study and control groups. There was not a significant difference in age at admission, gestational age and weight between the study and control groups $(P>0.05)$. there was not a significant difference in WBC and thrombocyte count among the values at admission, $24^{\text {th }}$ hour and end of therapy in the study group $(P>0.05)$. $\mathrm{B} / \mathrm{N}$ ratio was higher in the study group than the control at the beginning $(P>0.05)$. However, there was not a significant diffrence in $\mathrm{B} / \mathrm{N}$ ratio among the values at admission, 24 th aour and end of therapy in the study group $(P>0.05)$. Both serum CRP and
IL-6 livels were foung to be significantly higher than those of control subjects at the beginning $(P<0.05)$. Similarly, the values obtained on the $24^{\text {th }}$ hour were also elevated. However, at the end of therapy both decreased to normal level $(P<0.05)$ (Tab. 1). When compating the results of survivors and deaths, we found statistically significant difference in WBC count and serum IL- 6 levels between the groups (Tab. 2).

\section{Discussion}

Numeous studies have been performed to determine the raltionship between cytokins and neonatal sepsis in the literature $(1,4,5,6,9,10,11,12,14,15)$. They showed that both serum CRP and IL-6 concentrations elevated in infants with sepsis, and some of them revealed that the best predictors of infection were the combination of the initial IL-6 valute and CRP value after 24 h. $(1,6,7,11)$. Kallman et al.

Tab. 1: Clinical and laboratory findings of the study and control groups.

\begin{tabular}{|c|c|c|c|}
\hline Parameters & Study Group (n: 30) & Control Group (m: 10) & $P$ \\
\hline Age at admission (day) & $10.6 \pm 1.8$ & $4.9 \pm 0.5$ & $>0.05$ \\
\hline Gestational age (week) & $38.1 \pm 0.34$ & $38.5 \pm 0.52$ & $>0.05$ \\
\hline Weight (g) & $2860 \pm 137$ & $3260 \pm 217$ & $>0.05$ \\
\hline Hemoglobin $(\mathrm{g} / \mathrm{dl})$ & $12.68 \pm 0.55$ & $15.01 \pm 0.43$ & $>0.05$ \\
\hline $\begin{array}{l}\text { WBC count }\left(/ \mathrm{mm}^{3}\right) \\
\text { At the beginning } \\
\text { On the } 24^{\text {th }} \text { hour } \\
\text { At the end of therapy }\end{array}$ & $\begin{array}{c}12,657 \pm 2518 \\
9466 \pm 1614 \\
9033 \pm 941\end{array}$ & $11,370 \pm 1140$ & $>0.05$ \\
\hline $\begin{array}{l}\text { Band/Neutrophil ratio } \\
\text { At the beginning } \\
\text { On the } 24^{\text {th }} \text { hour } \\
\text { At the end of therapy }\end{array}$ & $\begin{array}{l}0.14 \pm 0.03 \\
0.12 \pm 0.01 \\
0.10 \pm 0.01\end{array}$ & $0.08 \pm 0.008$ & $<0.05$ \\
\hline $\begin{array}{l}\text { Thrombocyte count } \\
\text { At the beginning } \\
\text { On the } 24^{\text {th }} \text { hour } \\
\text { At the end of therapy }\end{array}$ & $\begin{array}{l}199,710 \pm 22,798 \\
197,440 \pm 45,144 \\
191,660 \pm 32,640\end{array}$ & $225,500 \pm 31,617$ & $<0.05$ \\
\hline $\begin{array}{l}\text { CRP }(\mathrm{mg} / \mathrm{dl}) \\
\text { At the beginning } \\
\text { On the } 24^{\text {th }} \text { hour } \\
\text { At the end of therapy }\end{array}$ & $\begin{array}{c}20.58 \pm 6.96 \\
29.56 \pm 8.3 \\
4.9 \pm 1.7 \\
\end{array}$ & $2.92 \pm 1.31$ & $<0.05$ \\
\hline $\begin{array}{l}\text { Serum IL-6 }(\mathrm{pg} / \mathrm{ml}) \\
\text { At the beginning } \\
\text { On the } 24^{\text {th }} \text { hour } \\
\text { At the end of therapy }\end{array}$ & $\begin{array}{c}359.86 \pm 90.83 \\
110.03 \pm 56.06 \\
3.96 \pm 2.10\end{array}$ & $5.11 \pm 1.94$ & $<0.05$ \\
\hline
\end{tabular}

Tab. 2: Laboratory findings of the survivors and deaths.

\begin{tabular}{|l|c|c|c|}
\hline & \multicolumn{2}{|c|}{ Sepsis Group (n:30) } & $P$ \\
\hline Parameters & Survivors & Deaths $(\mathrm{n}: 4)$ & 0.005 \\
\hline WBC count $\left(/ \mathrm{mm}^{3}\right)$ & $11,184 \pm 973$ & $4375 \pm 857$ & $>0.05$ \\
\hline Band/Neutrophil ratio & $0.12 \pm 0.01$ & $0.28 \pm 0.12$ & $>0.05$ \\
\hline Thrombocyte count $\left(/ \mathrm{mm}^{3}\right)$ & $196,576 \pm 19,696$ & $171,500 \pm 16,271$ & $>0.05$ \\
\hline CRP $(\mathrm{mg} / \mathrm{dl})$ & $21.72 \pm 8.0$ & $13.15 \pm 2.9$ & 0.04 \\
\hline IL-6 $(\mathrm{pg} / \mathrm{ml})$ & $336.3 \pm 68.7$ & $516.8 \pm 238.7$ & \\
\hline
\end{tabular}


(9) noted thal IL-6 contributes to the diagnosis of sepsis faster than CRP. Silveira et al. (15) and de Bont et al. (5) noted that the combination of TNF-alpha and IL- 6 determinations appeared to be a good predictor of neonatal sepsis. In our study both serum CRP and IL-6 levels were found to be significantly higher than those of control subjects at the beginning $(P<0.05)$. Similarly, the values obtained on the $24^{\text {th }}$ hour were also elevated and they were within normal ranges at the end of therapy.

Dollner et al. (7) compared six infalmmatorz mediators [CRP, Il-6, soluble TNF receptors (p55 and p75) and soluble adhesion molecules (ICAM-1, E-selectin)] as early diagnostic tests for neonatal sepsis, and studied the possible benefit of combining parameters. They noted that CRP performed best as a diagnostic test for neonatal sepsis. Diagnostic accuracy was further improved by combining CRP and IL-6, where as the other parameters (p55, p75, ICAM-1 and E-selectin) added no further diagnostic information (7). In the other study of the same authors similarly it was noted that used in combination with CRP, IL-6 seems to be a valuable parameter in the early diagnosis of neonatal infections (6). Kuster et al. (10) recorded that interleukin-1 receptor antagonist and IL- 6 are superior to cICAM-1 and CRP as predictors of sepsis 1 or more days before clinical diagnosis (10). In our study we found similar findings in both serum CRP and IL-6 levels. Therefore, we think alone serum CRP levels which is a simple method may be used in the diagnosis of neonatal sepsis. However, WBC and serum IL-6 levels may be useful to establish mortality, because there was a statistically significant difference for these parameters between the survivors and deaths $(P<0.05)$.

\section{References}

1. Buck C, Bundschu J, Gallati H, Bartmann P, Pohlandt F. Interleukin-6: a sensitive parameter for the early diagnosis of neonatal bacterial infection. Pediatrics 1994;93:54-8.
2. Caksen H, Züksel S, Öztürk MK, Sümerkan B, Coskun A. Use of acridine orange leukocyte cytospin test in diagnosis of neonatal sepsis. J Paediatr Child Health 2001;37:523.

3. Darmstadt GL. Infections of the neonatal infants. In: Behrmann RE, Kliegman RM, Jenson HB, eds. Textbook of paediatrics. $16^{\text {th }}$ ed. Philadelphia: WB Saunders, 2000:538-52.

4. de Bont ES, Martens A, van Raan et al. Tumor necrosis factor-alpha, interleukin1 beta, and interleukin-6 plasma levels in neonatal sepsis. Pediatr Res 1993;33:380-3

5. de Bont ES, Martens A, van Raan et al. Diagnostic value of plasma levels of tumor necrosis factor alpha (TNF alpha) and interleukin-6 (IL-6) in newborns with sepsis. Acta Paediatr 1994;83:696-9.

6. Doellner H, Arnzten KJ, Haereid PE, Aag S, Austgulen R. Interleukin-6 concentrations in neonates evaluated for sepsis. J pediatr 1998;132:295-9.

7. Dollner H, Vatten L, Austgulen R. Early diagnostic markers for neonatal sepsis: comparing C-reactive protein, interleukin-6, soluble tumour necrosis factor receptors and soluble adhesion molecules. J Clin Epidemiol 2001;54:1251-7.

8. Harris MC, Costarino AT Jr, Sullivan JS et al. Cytokine elevations in critically ill infants with sepsis and necrotizing enterocolitis. J Pediatr 1994;124:105-11.

9. Kallman J, Ekholm L, Eriksson M., Malmstrom B, Schollin J. Contribution of interleukin- 6 in distinguishing between mild respiratory disease and neonatal sepsis in the newborn infant. Acta Paediatr 1999;88:880-4.

10. Kuster $\mathrm{H}$, Weiss $\mathrm{M}$, Willeitner AE et al. Interleukin-1 receptor antagonist and interleukin-6 for early diagnosis of neonatal sepsis 2 days before clinical manifestation. Lancet 1998:352:1271-7.

11. Magudumana MO, Ballot DE, Cooper PA et al. Serial interleukin-6 measurements in the early diagnosis of neonatal sepsis. J Trop Pediatr 2000;46:267-71.

12. Mehr SS, Doyle LW, Rice GE, Vervaart P, henschke P. interleukin-6 and interleukin-8 in newborn bacterial infection. Am J Perinatol 2001;18:313-24.

13. Nicholson JF, Pesce MA. References ranges for laboratory tests and procedures. In: Behrman RE, Kliegman RM, Jenson HB, eds. Textbook of paediatrics. $16^{\text {th }}$ ed. Philadelphia: WB Saunders, 2000:2185-7.

14. Özdemir A, Oygur N, Gültekin M, Coskun M, Yeğin O. Neonatal tumor necrosis factor, interrleukin-1 alpha, inteleukin-1 beta, and interleukin-6 response to infection. Am J perinatol 1994;11:282-5.

15. Silveira RC, Procianoy RS. Evaluation of interleukin-6, tumour necrosis factoralpha and interleukin-1 beta for early diagnostic of neonatal spsis. Acta Paediatr 1999;88:647-50.

Submitted April 2002.

Accepted June 2002.

Dr. Dilara Içă̆asioğlu, Cumhuriyet University, Faculty of Medicine, Department of Pediatrics, Sivas, Turkey. e-mail: sense70@hotmail.com 